\title{
Doing Things with Metaphors in Contemporary China Analysing the Use of Creative Metaphors in the Discourse on the Chinese Dream
}

\author{
Beatrice Gallelli \\ (Università Ca' Foscari Venezia, Italia)
}

\begin{abstract}
The 'Chinese dream' sums up China's goals in the twenty-first century. Since its first appearance in 2012, the concept of the Chinese dream has been the core of Xi Jinping's "new thoughts, new ideas and new arguments". At the 19th National Congress of the Communist Party of China it was elevated as one of the guiding principles of 'Xi Jinping Thought on Socialism with Chinese Characteristics for a New Era', which represents the latest effort towards the Sinicization of Marxism. This paper aims at casting light on whether the discourse on the Chinese dream carries new contents or is based on old concepts 'camouflaged' as new. To do so, it will analyse the ideological implications of those 'creative metaphors' that compose the discursive mosaic of the Chinese dream as used by Xi Jinping in his political speeches. Drawing on the studies on conceptual metaphors and frame analysis, this study analyses those metaphorical expressions that are purposely outlined in the transcription of the speeches with the aim of signaling the originality of "Xi's language style". The final aim is to provide insight into what these 'creative metaphors' are doing in contemporary China. Results show that 'creative metaphors' in the discourse on the Chinese dream are meant to set the agenda on revitalising morality within the Party as well as 'unifying' values in today's Chinese society, and most of them are far from being new in Chinese political discourse.
\end{abstract}

Summary 1 Introduction. - 2 Background: Xi Jinping's Power and His Political Communication. - 3 Why Metaphors Matter: Metaphors as Framing Devices. - 4 Case Studies and Method. - 5 Creative Metaphors in the Political Speeches of Xi Jinping: Framing Values . - 5.1 Problem Definitions and Evaluations. - 5.2 Remedies. - 6 Conclusion: the Ideological Implications of Xi Jinping's Use of Creative Metaphors.

Keywords Chinese dream. Xi Jinping. Chinese official discourse. Frame analysis. Metaphors. 


\section{Introduction}

The concept of Zhōngguó mèng 中国梦 'Chinese dream' - or 'China dream' $^{1}$ - sums up the Party-state's goal for China in the twenty-first century, while signaling a departure from previous political slogans and concepts: the concept of the Chinese dream not only represents the last manifestation of yǔ shí jù jìn 与时俱进 'keep abreast of the time' by the Chinese political discourse (Chen Rudong 2017), but also offers a very optimistic image for the future of the country (Scarpari 2015, Lavagnino 2017). ${ }^{2}$ Indeed, the current generation of Chinese leaders led by Xi Jinping chose the metaphor of the dream as a novel way to revitalize an old goal pursued by China since Sun Yat-sen (1866-1925), i.e. Zhōnghuá mínzú wěidà fùxīng 中华民族伟大复兴 the 'great rejuvenation of the Chinese nation'. ${ }^{3}$

In the big metaphorical "metanarrative" (Fasulo 2016, 13) of the Chinese dream, other metaphors have been put forward by Xi to shape China's past, frame the present and project the nation towards its future. This paper concerns the use of creative metaphors as a means of setting the agenda, defining issues and framing social reality in today's China. From this perspective, metaphors have the potential of 'doing things', echoing Schoenhals' (1992) seminal work, Doing Things with Words in Chinese Politics: Five Studies. In his study, the Swedish scholar analyzes tífă 提 法 (formalized political expressions) as "perlocutionary acts" (Schoenhals $1992,5)$ and therefore as a form of power in China. By doing so, Schoenhals sheds light on the role of language in the process of ideological creation and imposition.

This paper follows in the footsteps of Schoenhals's (1992) study and attempts at contributing to the research on actions performed by linguistic acts as constitutive of 'agency in and of language' (Duranti 2004) in Chinese official discourse. Drawing upon the notion of frames (Goffman

1 The official translations opt for 'Chinese dream' in order to provide the nuance that this is a goal pursued by the Chinese people rather than by the Party-state alone. However, 'Chinese dream' sounds like an imitation of the 'American dream', in Chinese Měiguó mèng 美国梦. This study decides upon 'Chinese dream', because it agrees with Fumian (2013) in seeing the Chinese dream as an attempt to borrow "the language of the other superpower in order to look similar and at the same time different to its new superpartner".

2 This article is a revised version of a paper presented at the Doctoral Seminar Inerzia e Solerzia del Testo (5-6 December 2017, Ca' Foscari University, Venice). I would like to thank Prof. Patrick Heinrich for his observations and suggestions. Special thanks also to Prof. Fiorenzo Lafirenza, Prof. Maurizio Scarpari, Prof. Pohl Karl-Heinz, Prof. Sean Golden, as well as the anonymous reviewers for their comments on the first draft of the paper.

3 As Yan Xuetong - cited in Callahan (2014) - explains, "the great rejuvenation of the Chinese nation" has been employed by previous Chinese leaders in order to mark the beginning of a new historical era. However, Xi Jinping's concept of rejuvenation is different in that he points out people can achieve this goal within their lifetime. 
1974) and conceptual metaphors (Lakoff, Johnson 2003), this study will analyze the use of 'creative metaphors' in contemporary Chinese political discourse and their ideological implications in today's China. In other words, the aim of this research is to examine the use of metaphors deemed as 'new' and that are meant to underpin the discourse on national rejuvenation for 'a new era'. The final objective is to cast light on whether they convey new thoughts or are merely another way of "manipulating the form rather than the content of discourse" (Schoenhals 1992, 21).

\section{Background: Xi Jinping's Power and His Political Communication}

In October 2017 Xí Jìnpíng xīn shídài Zhōngguó tèsè shèhuì zhǔyì sīxiăng 习近平新时代中国特色社会主义思想 'Xi Jinping Thought on Socialism with Chinese Characteristics for a New Era', abbreviated as Xí Jìnpíng sīxiăng 习近 平思想 'Xi Jinping Thought', was officially enshrined in the Pantheon of Chinese political ideology. One year before, in October 2016, Xi was elevated to héxīn 核心 the 'core'4 of the collective leadership and, soon after putting forward his 'thought', Xi has been labelled linngxiù 领袖 'leader', which

means more than just a leader. It is often bestowed to a leader who enjoys the highest prestige, who is the most capable and who is widely recognized by the entire Party. (Bai Tiantian 2018)

Much has been written about the political power acquired by Xi Jinping due to his ideological contribution entering into the Party's Constitution, alongside Marxism-Leninism, Mao Zedong Thought, Deng Xiaoping Theory, 'The important thought of the Three Represents' and the 'Scientific Outlook on Development' (Miranda 2017; Buzzetti, Spalletta 2017; WoLap Lam 2017). Before Xi, only Mao Zedong and Deng Xiaoping had their names written in the Party's constitution, and only the Great Helmsman saw his 'thought' written in the constitution while he was still in power. Therefore, 'Xi Jinping Thought on Socialism with Chinese Characteristics for a New Era' marks a departure from the previous political procedure and Xi Jinping stands out for the great accumulation of power in his hands.

This power paves the way for Xi to stay in office indefinitely. The Central Committee of the CPC asked for an amendment of the country's constitution, which was to remove the limit of serving a maximum of two terms (Xinhua 2018a) and that was set up in 1982. Therefore, it is likely that Xi

4 Concretely speaking, being a core leader does not imply anything. Symbolically, however, it has much importance, at least within the Party. Xi Jinping's predecessor, Hu Jintao, did not enjoy the same prestigious status. 
will keep his leading role even after 2023, the year settled on for the end of his mandate.

This status of 'primus super pares' - as opposed to 'primus inter pares' - was achieved through five years of strong anti-corruption and 'mass line' campaigns, a massive concentration of power held over the party, the state and the military fields, enforcement of discipline among Party's members at all levels, as well as a revival of ideological control over the academia, the communications media and the social media. All this has been accompanied by populist propaganda work focusing on Xi Jinping's skills in political communication, aiming at highlighting Xi Jinping's ability to shape China's guójiā xíngxiàng 国家形象 'national image' (Li Weihong 2017, 40).

Xi Jinping's speeches delivered both at home and abroad are described as having a jí qiáng de huàyǔ lì 极强的话语力 'strong discursive force' (Liu Jin 2013 , 569) and have been the object of many newspaper articles, academic papers as well as books. ${ }^{5} X i ́$ shì yǔyán 习式语言 'Xi's language style' has been described as having a yōuliáng wénfēng 优良文风 'refined speech style' (Ma Zhong, Li Shuanggen 2014), a Zhōngguó wèi 中国味 'Chinese taste' (Dong Weiwu, Cheng Yin 2014, 10) as well as being kǒuyǔ huà, jiēdì qì 口语化、接地气 'colloquial and down-to-earth' (Zhang Haifa, Hu Zhongbing 2014) and, therefore, a fànběn 范本 'model' for officials and cadres at all levels (Yao Lijun, Li Chunmei 2016).

Entire volumes have been dedicated to gathering the rhetorical devices most used by Xi. Two volumes edited by Renmin ribao pinglun bu are devoted to Xi Jinping's literary references (2015; 2018a) and another to anecdotes (2017). For this latter volume, a version has also been published for kids (2018b).

Moreover, Chen Xixi (2014) compiled twenty-five metaphors, twenty popular sayings and seventy quotations from the Chinese classical literature used by $\mathrm{Xi}$ in speeches delivered in the aftermath of the eighteenth Party's National Congress until May 2014 in both domestic and international contexts. Surfing the wave of the success of this book, as stated in the editorial notes (Liu Zhihui 2017, 1), Liu Zhihui collected twenty metaphors, nineteen popular sayings and twenty quotations from Chinese classics, employed by Xi in those speeches dealing with guófáng 国 防 'national defense' and jūndui 军队 'armed forces'. In addition to these books, drawing upon the chéngyǔ 成语 - píngyìjìnrén 平易近人 'plain and simple' - in the title of Chen Xixi (2014) and Liu Zhihui (2017), Xinhua

5 It is worth noting that in the cross hairs of the Party's propaganda are not merely the so-called popular masses, but also the academia. As a matter of fact, the study of Xi Jinping's speeches has been a well-founded field of research since 2013 (Huang 2014) and continues to be a pillar of propaganda work even after the nineteenth Party Congress with the creation, in universities, of special research centers devoted to Xi Jinping Thought (Bandurski 2017). 
dedicates a section of its website to Xi Jinping's language and rhetorical devices, including metaphors, calling it píngyǔ jìn rén 评语近人 'comments close to people'. For instance, just before the liănghuì 两会 'two sessions' held in March 2018 - National People's Congress and Chinese People's Political Consultative Conference - the news agency Xinhua had published an article collecting the metaphors employed by $\mathrm{Xi}$ in his speeches at the 'two sessions' that had been held over the past five years (Xinhua 2018b). The same metaphors are then translated into English and arranged in a colourful slide-show by China Daily, in its section called "Xi's Moments" (China Daily 2018).

The use of metaphors is not limited to domestic politics but involves China's foreign policy as well. Many metaphors have been put forward to shape the Belt and Road Initiative (BRI): an editorial by People's Daily selects ten metaphors used by $\mathrm{Xi}$ to outline the principles guiding the project (Renmin wang 2017).

In conclusion, Xi Jinping's political communication has been defined as a xīn de guānhuà 新的官话 'new official language' in contrast to the kōnghuà, tàohuà, fèihuà 空话、套话、废话 'empty talks, formulaic language and superfluous words' that characterize the old kind of official language (Gao Shan 2015). In other words, it seems that Xi Jinping is closing the rift between 'ganbunese' and 'baixingese', using Thøgersen's (2006) labels for political language and the code spoken by common people respectively. The rift between official language and the one of everyday life is by no means a feature of the Chinese context, since it can be found all over the world. What is interesting here is that Xi's 'new' kind of political communication is deemed to be the key index of Xi Jinping's xīn sīxiăng, xīn guāndiăn, xīn lùnduàn 新思想、新观点、新论断 'new thoughts, new ideas, new arguments' (Peng Longfu 2015). The great importance attached to these publications focusing on Xi Jinping's communication skills or gathering of his speeches was upheld by the fact that all these books and volumes occupied the shelves of many bookstores in Beijing for the nineteenth Party's National Congress held in October 2017 (Wang Zhen 2017).

\section{Why Metaphors Matter: Metaphors as Framing Devices}

Metaphors are a hub where many fields of research cross with each other: many authors in the fields of philosophy, rhetoric, linguistics, aesthetics, semiotics, psychology, etc. have written about metaphors. In recent years, a new wave of interest in metaphors has arisen especially in the aftermath of the Conceptual Metaphor Theory (Lakoff, Johnson 2003), whose basic claims can be summed up as follows: a) the pervasiveness of metaphors in human language and thoughts; b) the cognitive nature of metaphors, i.e. metaphors structure our thoughts, helping us grasp abstract matters 
by means of familiar and accessible concepts based on bodily experience. Metaphors are therefore defined as the interaction between two conceptual domains. That is, an object, an event or an issue - the "target domain" in Lakoff and Johnson and the "tenor" in Richards (1936) ${ }^{6}$ - is another object, event, or issue - the "source domain" (Lakoff, Johnson) and the "vehicle" (Richards).

Setting aside the debate on the cognitive function of metaphors, what this paper is interested in is the pragmatic view on metaphors, that is how metaphors "achieve particular communication goals" (Charteris-Black $2004,247)$. In other words, the focus is on how metaphors can do things in social and political reality.

Metaphors imply not only a semantic mapping between the two entities, but also evaluative connotations attached to the tenor - the "direct application” in Ottati et al. $(2013,189)$ and the xiūcí gōngnéng 修辞功能 'rhetorical function' in Chen Rudong $(2014,195)$. In other words, vehicles carrying positive connotations raise positive evaluations of the tenor; whereas negative vehicles yield the opposite effect. So, for instance, during the Cultural Revolution (1966-1976) when human beings were labelled as animals, they were also treated accordingly. As Lu Xing explains:

by using terms, such as 'parasites', 'blood suckers', 'vermin', etc., China's class enemies were treated as less than human, and the extreme measures taken against them were deemed morally justified. $(2004,69)$

However, it is worth pointing out that sometimes the 'direct effect' is not so 'direct':

direct application does not necessarily produce an effect on attitudes toward the communication target that is congruent with the overall valence of the metaphor source (vehicle). (Ottati et al. 2013, 189)

It is possible that only some of the features of the vehicle are attached to the tenor. To explain this, Ottati et al. (2013) provide the example of the metaphor "government is a baby" (190) claimed by the American President Reagan. In this metaphor, only the negative features of babies are attributed to the government, even though the general evaluation of babies is positive.

A second important implication is that metaphors foreground some features of a perceived reality, obscuring others. This is called the "highlighting and hiding" in Lakoff and Johnson (2003, 22-5) and the "selective

6 Richards' view on metaphors and the metaphorical nature of thought is linked to his understanding of cognitive processes, which allow to refer to a category or a class by moving from a set of features of an individual and specific phenomenon. 
processing" in Ottati et al. (2013, 190-2). This principle was applied to political communication by Edelman even before the Conceptual Metaphor Theory, in his oft-cited passage:

each metaphor intensifies selected perceptions and ignores others, thereby helping one to concentrate upon desired consequences of favored public policies and helping one to ignore their unwanted, unthinkable, or irrelevant premises and aftermaths. Each metaphor can be a subtle way of highlighting what one wants to believe and avoiding what one does not wish to face. (Edelman 1971, 67)

In line with the Metaphorical Framing Model proposed by Ottati et al. (2003) - though never quoting any of Ottati's works - Burgers et al. (2016) offer an integration of the literature on figurative language from the field of cognitive linguistics with the communication-scientific literature on framing. The authors rightly point out that, by considering the conceptual nature of figurative language, metaphors fulfil one or more of the important functions of framing in communication as distinguished by Entman (1993). Indeed, drawing on Goffman's (1974) notion of frame, Entman suggests that

to frame is to select some aspects of a perceived reality and make them more salient in a communicating text, in such a way as to promote a particular problem definition, causal interpretation, moral evaluation, and/ or treatment recommendation for the item described. (Entman 1993, 52; emphasis in the original)

Commenting on frame analysis conducted by some scholars in the aftermath of Entman's contribution, Reese (2007) replies that many works that label their approaches as frame analysis on media texts are actually content analysis, overlooking that "it is precisely the way that certain attributes come to be associated with particular issues that should concern framing analysis" (Reese 2007, 152; emphasis in the original). In response to this, the present paper, in agreement with Burgers et al. (2016), sees metaphors as framing devices ${ }^{7}$ and suggests that the analysis of figurative language can help to shed light on the way that some features are attached to specific events and issues. In particular, the present paper seeks to delve into the ideological implications of the creative metaphors

7 Burgers et al. (2016) suggest that metaphors are both framing and reasoning devices. However, in light of the definition of frames and framing in the literature, such as the one above provided by Entman, it is clear that the notion of frame contains in itself the nuance of reasoning. Therefore, Burgers et al. (2006), while being right in integrating the two approaches, seem to overlook the role of frames in discourse. 
used by Xi Jinping in the context of his speeches delivered at home that apparently manifest Xi Jinping's new political communication.

\section{Case Studies and Method}

The data to be analysed is a corpus of Xi Jinping's political speeches collected in the volumes Xí Jìnpíng tán zhìguó lí zhèng 习近平谈治国理政 The Governance of China (Xi Jinping 2014a, 2014b) and Xí Jìnpíng tán zhìguó lǐ zhèng dì èr juăn 习近平谈治国理政第二卷 The Governance of China II (Xi Jinping 2017a, 2017b). ${ }^{8}$ The former volume gathers Xi's talks and writings addressed between 15 November 2012 and 13 June 2014, while the latter those from August 2014 to September 2017. Among all the speeches collected in these two volumes, this study focuses on those contained in the chapters on "Socialism with Chinese characteristics", "The Chinese dream" and "Culturally advanced China" in The Governance of China (Xi Jinping 2014b), and "Socialism with Chinese characteristics and the Chinese dream" and "Cultural confidence" in The Governance of China II (Xi Jinping 2017b).

The choice of focusing on the talks and writings contained in these chapters has been made for two reasons. The first one concerns the concept of the Chinese dream and the structures of the two volumes. Indeed, while in the first volume, this concept was treated separately from the political ideology defined as Socialism with Chinese Characteristics in the second volume (Xi Jinping 2017b) it was reframed and linked to the political ideology that guides the country. This is the reason why both chapters in the first volume were included for the analysis of the use of creative metaphors in relation to the discourse on the Chinese dream.

The second reason is tightly bound to the role that Chinese culture has acquired in contemporary China since Xi took the reins of the Party and the Country (Scarpari 2015, Ambrogio 2017). The key part played by traditional culture in the discourse on the Chinese dream is clear from the title of the chapter devoted to Chinese culture. Indeed, the title Jiànshè shèhuì zhǔyì wénhuà qiángguó 建设社会主义文化强国 (Building a Strong Socialist Cultural Nation) (Xi Jinping 2014a, 155) recalls the need to enhance the cultural soft power of the country as a must for realizing the dream of a 'strong nation'. In the work report pronounced in October on the occasion of the nineteenth Party Congress, Xi once again emphasizes the tight bond

8 For the English translations, the official translations in Xi Jinping (2014b, 2017b) will be used including also the title of these two volumes. When the source of the English translation is not indicated, translations are by the Author. 
between what is defined as the fourth self-confidence, ${ }^{9}$ i.e. wénhuà zìxìn 文 化自信 'cultural confidence', and the realization of the 'great rejuvenation of the Chinese nation':

\section{文化兴国运兴，文化强民族强。没有高度的文化自信，没有文化的繁荣兴盛，就没有 中华民族伟大复兴。(Xi Jinping 2017c)}

Our country will thrive only if our culture thrives, and our nation will be strong only if our culture is strong. Without full confidence in our culture, without a rich and prosperous culture, the Chinese nation will not be able to rejuvenate itself.

Therefore, it could be argued that the discourse on revitalizing the role of culture in China is of particular importance within the metanarrative on the Chinese dream of great rejuvenation of the Chinese nation. Based on this consideration, this study takes the talks and writings contained in the above-mentioned chapters as case studies for the analysis of how creative metaphors in the discourse on the Chinese dream are ideologically creative.

Before commenting on the methodology, it is worth noting that the speeches and writings included in these chapters are mainly delivered in domestic contexts but are not limited to a single and specific audience. This has two implications: first, the Chinese dream works as a metanarrative mainly for the domestic context. Indeed, although Xi Jinping has promoted international versions of the Chinese dream, such as an Yàzhōu mèng 亚洲梦 'Asian dream', a Yàtài mèng 亚太梦 'Asia-Pacific dream' as well as a shijiè mèng 世界梦 'World dream', the Chinese discourse abroad is mainly dominated by the one on the yīdài yīlù 一带一路 'One Belt, One Road' - recently renamed 'Belt and Road Initiative' -, which nonetheless share many common ideological assumptions with the discourse on the Chinese dream held at home. Second, the fact of not having a specific audience for the speeches dealing with the Chinese dream underpins the role of the discourse on the Chinese dream as a metanarrative, functioning for both the Party and Chinese civil society.

Regarding the method, in general, for the individuation of both conventional and creative metaphors, the criterion of incongruity is useful (Lu, Ahrens 2008). That is, the incongruity between the literal sense of an expression and the context when it occurs guides the individuation of metaphorical expressions. This criterion can be applied for both conventional and creative metaphors, i.e. respectively those that are no longer

9 Initially, there were three 'confidences' - dàolù zìxìn 道路自信 (confidence in our road), lǐlùn zìxìn 理论自信 (confidence in our theories) and zhìdù zìxìn 制度自信 (confidence in our institutions). The fourth confidence was added later by Xi (Feng Pengzhi 2016). 
perceived as metaphorical expressions and those metaphors that require more mental processing to be understood (Goatly 2007, 22). Specifically, for creative metaphors, Müller (2005) distinguishes six strategies for using them in political speeches and, among these strategies, "make the audience aware of a metaphor" (59) by markers and hedges is the one chosen in this paper for the individuation of Xi Jinping's creative metaphors. Indeed, in the original texts creative metaphors are usually closed by inverted commas to highlight their originality. The present research aims at pointing out whether these expressions can be considered to be original. To do so, the phase of analysis consists of three steps: 1) classifying metaphors into cognitive frames as their source domains; 2) understanding whether the metaphors can be considered as new or not; 3) pinpointing their discursive function by placing them in relation to the wider discursive landscape shaped by the goal of realizing the Chinese dream.

\section{Creative Metaphors in the Political Speeches of Xi Jinping: Framing Values}

In all the speeches analysed, a total amount of twenty-two creative metaphors have been found. Although these metaphors are employed in different contexts, there is a common thread linking all of them, except for one. This common thread is the goal of setting the agenda on the need to revitalize the role of political ideology and morality among the members of the Communist Party of China (CPC) and 'unifying' values in Chinese society. Only the expression niúbízi 牛鼻子 (Xi Jinping 2017a, 23) literally meaning 'the nose of an ox' is used in relation to the necessity of attending to general plans while solving crucial specific problems. Whereas all the other metaphors are meant to stress the need for solid moral foundations shared by the various parts of the Chinese society.

Nonetheless, these metaphors pursue this goal in different ways. For the analysis, it is useful to draw upon the framing functions pointed out by Entman (1993): problem definitions, causal interpretations, evaluations and remedies. Problem definitions and evaluations are treated together, because metaphors themselves carry evaluations, while causal interpretations are skipped by Xi's use of creative metaphors. In the following pages representative examples are illustrated and explained. 


\subsection{Problem Definitions and Evaluations}

Given the role of boosting common values through these creative metaphors, it is not surprising that many of them belong to metaphorical associations that structure the discourse on the ongoing anti-corruption campaign. In their study on a corpus of twenty-one official documents, including some of Xi's speeches, party statements and newspaper reports, Jing-Schmidt and Peng (2017) identify four main conceptual metaphors framing the discourse on corruption under Xi Jinping. These are: 'corruption is disease', 'corruption is vermin', 'corruption is a weed' and 'corruption is slovenly'. No one of these metaphors is new in Chinese political discourse. All of them can be trace back to the Maoist era. ${ }^{\mathbf{1 0}}$ Many creative metaphors individuated in Xi Jinping's speeches belong to these metaphorical associations. For instance, starting with the most famous catch phrase in Xi's anticorruption discourse, i.e. lăohŭ cāngyíng yīqǐ dă 老虎苍蝇一起打 'catching both tigers and flies', the metaphors lăohǔ 老虎 'tigers' and cāngyíng 苍蝇 'flies', for corrupt powerful officials and corrupt local cadres respectively, belong to 'corruption is vermin'. Animals in general carried negative connotations in Chinese official discourse during the Mao years (Link 2013, 269) and some of them still do as is the case of tigers and flies. In particular, the metaphor of 'tigers' in the discourse on anticorruption in China is nothing new: for the two anticorruption movements known as Three-Anti Campaign and Five-Anti Campaign launched in 1951, those accused of corruption were called 'tigers' (Lu 2017, 194).

In addition, three creative metaphors belong to the domain of disease: $q u e \bar{g}$ gài 缺钙 'lack of calcium'; ruăngǔ bìng 软骨病 'osteomalacia' and jī wúlì 肌无力 'myasthenia'. For the disease metaphors, the expressions 'lack of calcium' and 'osteomalacia' were indeed used by Xi for the first time in relation to party members in his speech at the first group study session of the Political Bureau of the eighteenth CPC Central Committee:

\section{对马克思主义的信仰, 对社会主义和共产主义的信念, 是共产党人的政治灵魂, 是共产 党人经受住任何考验的精神支柱。形象地说, 理想信念就是共产党人精神上的 “钙”, 没有理想信念，理想信念不坚定，精神上就会 “缺钙”就会得“软骨病” (Xi Jinping 2014a, 15)}

Belief in Marxism and faith in socialism and communism are the political soul of communists, and the spiritual pillar enabling them to withstand all tests. Put figuratively, the ideals and convictions of Communists are the 'marrow' of their faith. Without, or with weak, ideals or convictions, they would be 'deprived of their marrow' and suffer from 'osteomalacia'.

10 See Jing-Schmidt and Peng $(2017,12)$ for the explanation of the Maoist origin of the metaphor 'corruption is disease'; Lu (2017, 193-8) for Maoist legacy in Xi Jinping's rhetoric; Link (2013) for the use of health (254) and animal metaphors (269). 
As Jing-Schmidt and Peng (2017) point out, the disease metaphor lies on the well-established metaphor of the body politics, according to which 'an institution is a human body'. This metaphor helps to conceive state institutions and political parties as one single body. The metaphor of the body politics is by no means Chinese specific - Musolff (2004) states for the political discourse in Europe that it has "a long tradition in political discourse and thought" (83). To prove the persistence of the body politics in Chinese discourse, in the excerpt above, besides the metaphorical expressions marked by inverted commas, also línghún 灵魂 'soul' belongs to the same domain stressing the spiritual dimension of this body politics.

The disease metaphor in its use of framing the need for reaffirming values is not only addressed to party's members, but also to other parts of the society. Indeed, the expression 'lack of calcium' appears again in Xi's speech addressed to students on the anniversary of the May Fourth Movement (Xi Jinping 2014a, 50). In addition, jī wúlì 肌无力 'myasthenia', belonging to the disease domain too, is employed to emphasize the 'Chinese characteristics' that social sciences and philosophy need to have. In his speech at the Seminar on Philosophy and Social Sciences held on 17 May 2016, Xi Jinping stressed the need for academia to "put forward subjective, original theories and views on the basis of studying Chinese conditions, and structure disciplinary, academic and discourse system with our own features" (Xi Jinping 2017b, 370). Being 'subjective' and 'original' here stands for foreign theories, especially European or America. In other words, it is less a matter of originality, and more the need to abide by those 'Chinese characteristics' defined by the Party-state. The discourse on 'Chinese characteristics' for the academia and intellectuals corresponds to the other side of the coin, which sees the war against 'western values' worsening under Xi Jinping. Against this backdrop, it is not surprising that the disease metaphors, specified in the expression 'myasthenia', are used in relation to the need for 'innovative theories', or better said, theories with 'Chinese characteristics', in the academia:

如果不能及时研究、提出、运用新思想、新理论、新办法, 理论就会苍白无力, 哲学 社会科学就会 ‘肌无力’。(Xi Jinping 2017a, 342)

Without the creation and application of new thoughts, concepts and methods through timely study, theories will be impotent in the face of reality, and philosophy and social sciences will suffer from 'myasthenia'.

The ideological weight of the disease metaphors in official discourse lies in three main implications. The first one is the direct effect of metaphors (Ottati et al. 2013), that is the negative connotations of a disease are directly attached to an issue, in this case the lack of morality within the party and the society. Second, the disease metaphors also come in very 
handy in hiding the cause of this issue. Indeed, while the lack of ideals and convictions are taken for granted as being the cause of a possible disease, no mention has been made of what causes this lack of morality. This is precisely because a debate for possible causes of the lack of common values in contemporary Chinese society may flow into a bigger discussion on the legitimacy of market-oriented reforms in a country led by a communist party. A third ideological implication of the disease metaphor is suggested by Fairclough $(1989,120)$ : "disease metaphors [...] tend to take dominant interests to be the interests of society as a whole, and construe expressions of non-dominant interests as undermining society per se". In this case, non-dominant interests are all those that do not belong to the Party-state led by Xi. Moreover, as was the case of animal metaphors, disease metaphors are by no means new in Chinese official discourse (Lu 2017, 195-6; Link 2013, 254-5).

However, the three ideological implications effective for disease metaphors cannot be applied to the metaphor sīrén jùlèbù 私人俱乐部 'private club' employed by Xi on 13 February 2017, at a study session on implementing the decision of the Sixth Plenary Session of the Eighteenth CPC Central Committee, which was attended by officials at the provincial and ministerial levels. In reaffirming the guiding role of the CPC Central Committee, Xi says:

如果党中央没有权威 [...] 党就会变成一盘散沙, 就会成为自行其是的“私人俱乐部”, 党的领导就会成为一句空话。(Xi Jinping 2017a, 21)

If the CPC Central Committee had no authority [...] the Party would have become fragmented and become a 'private club', turning the Party's leadership into empty voices. (Xi Jinping 2017b, 20-1)

'Private clubs' have no negative connotations per se. It acquires a negative tone within the context of discourse. Put differently, it is the metaphorical association between a political dăng 党 'party' that is called gòngchăn 共 产 'public' and a sīrén jùlèbù 私人俱乐部 'private club'. The opposition between the gòng 共 'public' and sī 私 'private' has a long history in China and the preference for the former over the latter is a cardinal principle in Confucianism (Cui 2007). ${ }^{\mathbf{1 1}}$ Therefore, here the negativity arises from, first, the association in and of itself, that is the one between a private club' and a communist party, and second from the unity-disunity duality. This second can be explained as follows: if the Party is a 'private club', it is separated from the rest of the community, which in turn would not listen to his commands. This unity-disunity duality is enhanced by the idiom $y \bar{\imath}$

11 I would like to thank Prof. Sean Golden for these points. 
pán săn shā 一盘散沙 'a sheet of loose sand', which recalls Sun Yat-sen's famous passage:

the Chinese people have only family and clan groups, there is no national spirit. Consequently, in spite of four hundred million people gathered together in one China, we are in fact but a sheet of loose sand. We are the poorest and weakest state in the world. (Sun Yat-sen cited in Wells 2001, 23)

Being a 'sheet of loose sand' made China at that time the subject of foreign imperialism. Therefore, this chengyu unavoidably triggers a negative evaluation.

In this case the link between restoring discipline and values within the Party and the metaphor may appear not as direct as it was for the other metaphors discussed above. However, to understand the deep implications of this metaphor, it needs to be considered in light of the process of regaining legitimacy that the anticorruption campaign has. Indeed, only if the Party is strong and united internally can it exercise power over the society. This meaning is conveyed by Xi also in 2015 at the fourth Plenary session of the eighteenth CPC Central Committee:

不全面从严治党，党就做不到“打铁还需自身硬”，也就难以发挥领导核心作用。(Xi Jinping 2017a, 24)

Without strengthening Party's discipline, the Party will not be 'a good blacksmith to forge good tools', and it will be difficult for the Party to play its role as the core of the leadership. (Xi Jinping 2017b, 24)

\subsection{Remedies}

Remedies consist first of all in boosting the shèhuì zhǔyì héxīn jiàzhíguān 社会主义核心价值观 'core socialist values'. ${ }^{12}$ Indeed, the expression kòu kòuzi 扣扣子 'do up the buttons' is employed in the speech at the seminar with students and professors of Peking University on 4 May 2014, in which Xi dedicates ample space to the promotion of these 'core values'. This expression 'do up the buttons' can be connected to the slovenly metaphor pointed out by Jing-Schmidt and Peng (2017) and mentioned above. This is precisely because, although it is not used in relation to the anticorrup-

12 These values are: fùqiáng 富强 'prosperity', mínzhǔ 民主 'democracy', wénmíng 文明 'civility', héxié 和谐 'harmony', zìyóu 自由 'freedom', píngděng 平等 'equality', gōngzhèng 公 正 'justice', făzhì 法治 'law-based governance', àiguó 爱国 'patriotism', jingyè 敬业 'dedication', chéngxìn 诚信 'integrity', yǒushàn 友善 'friendship'. For the translation of făzhì 'law based governance', this study follows the official Chinese choice (Golden 2015, 3). 
tion campaign - as in Jing-Schmidt and Peng (2017) -, it nonetheless aims to cast a negative light on the consequences of a lack of values in youth: "young people should 'button right' in the early days of their life" (Xi Jinping 2014b, 192) implying that 'core socialist values' should be inculcated in the mind of people since youth. ${ }^{13}$

Promoting these common values is also the link between the expressions zuìdà gōngyuē shù 最大公约数 'greatest common denominator' (Xi Jinping 2014, 168) and zǒng kāiguān 总开关 'main switch' (Xi Jinping 2017a, 44) which, apparently, do not have anything in common and do not share the same domain. However, considering in the linguistic contexts in which they are used, it appears that both are meant to lay emphasis on uniting values within the Party and in today's China at large. 'Greatest common denominator' is another metaphor employed in the speech at Peking University for the anniversary of the May Fourth Movement in 2014, while 'main switch' addressed to Party's members at the ceremony marking the ninety-fifth anniversary of the foundation of the CPC.

每一名党员干部都要 [...] 拧紧世界观、人生观、价值观这个“总开关”。(Xi Jinping 2017a, 44)

Each Party's member and official should [...] hold the main switch of the right worldview, outlook on life, and values.

我国是一个有着 1.3 亿多人口、56 个民族的大国，确立反映全国各族人民共同认 同的价值观 “最大公约数”, 使全体人民同心同德、团结奋进, 关乎国家前途命运, 关乎人民幸福安康。(Xi Jinping 2014, 168)

China is a big country with 1.3 billion people and fifty-six ethnic groups. Upon the recognition of the values with the 'greatest common denominator' by the people of all ethnic groups, they work with one heart and one mind to strive in unity. (Xi Jinping 2014b, 187)

However, although both metaphors, 'greatest common denominator' and 'main switch', are meant to set values at the center of the socio-political agenda, there is a slight difference in the way in which they perform their functions within the party and within Chinese society. In the first case, that is in the speech addressed to the Party, the ethical dimension of individual Party's members and officials is stressed, by saying měi yī míng dăngyuán gànbù 每一名党员干部 'each Party’s member and officials' instead of, for instance, simply dăngyuán gànbù 党员干部 'Party's members and officials'.

In the second case, 'greatest common denominator' wants to merge values by creating a collective identity embodied in the people of all

13 Interestingly enough, this speech is full of quotations from Chinese classics. For a deeper explanation of the relation between intertextuality and ideology, see Magagnin 2017. 
ethnic groups'. Indeed, among the many terms used to designate the Chinese general population - lăobăixìng 老百姓 'common people', rénmín 人 民 'people', qúnzhòng 群众 'masses', gōngzhòng 公众 'public', gōngmín 公 民 'citizens' - Xi choses the one which carries a specific political connotation. All these expressions are by no means "'neutral' words and forms" (Bakhtin 1981, 293), ${ }^{14}$ but rather they belong to the languages of diverse social groups, carrying the nuances of different professions, generations, political tendencies and worldviews. For the word 'people', during the Mao era, it used to designate the members of those social classes that zànchéng, yǒnghù hé cānjiā 赞成、拥护和参加 'support, uphold and participate in' (Wei Chuanguang 2016, 40) the construction of the socialist system, as opposed to the dírén 敌人 'enemies'. It goes without saying that, although in the aftermath of reforms and opening up it has been seen as a synonym of citizen, 'people' still carries positive connotations and a strong political 'taste'.

The political "taste" (Bakhtin 1981, 293) of 'the people' is even stronger in a context in which 'the people' should be, according to Xi, the referential object for literature and arts:

人民既是历史的创造者、也是历史的见证者，既是历史的 “剧中人”、也是历史的 “剧作者”。文艺要反映好人民心声, 就要坚持为人民服务、为社会主义服务这个根本 方向。(Xi Jinping 2017a, 314)

The people are both the creators and observers of history, and both its protagonists and playwright.

This is an extract of Xi's speech at the Forum on Literature and Art held in Beijing on 15 October 2014. The metaphors jù zhōng rén 剧中人 'protagonists' and jù zuòzhě 剧作者 'playwright' are meant to outline the political function of literature and art. Both in content and language, Xi's words evoke Mao Zedong's discourse at the Yan'an Forum, during which the Great Helmsman outlined the functions of art and literature as serving the people and pointed out that artists and writers must represent the everyday life of the working and peasant masses (Mao Zedong 1942). On one hand, Mao's call for revolution has been replaced by Xi's stress on the realization of the 'great rebirth of Chinese nation'; on the other hand, it remains the central task of art and literature to serve the people and socialism. For the aims of this research it is worth noting that, although the two metaphors signaled by inverted commas, i.e. 'protagonists' and 'playwrights', were not used by Mao Zedong in his speech in 1942, chuàng-

14 Bakhtin coined the expression 'heteroglossia' to describe the social diversity of codes within any language at any given moment of its historical existence. For Bakhtin, within a language, different varieties coexist and each of them bears the traces of their historical developments and contexts of use. 
zào zhě 创造者 'creators' directly quotes Mao's term, when he defined the people as zhège rénlèi shìjiè lìshǐ de chuàngzào zhě 人类世界历史的创造者 'creators of the history of the human world' (Mao Zedong 1942), and the two expressions wéi rénmín fúwù 为人民服务 'serve the people' and wèi shèhuì zhǔyì fúwù 为社会主义服务 'serve socialism' leave no doubt about the political tones of Xi Jinping's words. In this case, therefore, metaphors are indirectly connected to the goal of 'unifying values' in today's China.

\section{Conclusion: the Ideological Implications of Xi Jinping's Use of Creative Metaphors}

This study attempted at analyzing the ideological implications of 'creative metaphors' in the discourse of the Chinese dream as used by Xi Jinping in his political speeches. In particular, it has found that, first, a call to restore discipline and morality within the Party as well as unifying values within China's borders at large is the common thread linking various metaphors that apparently do not share any traits. In this way, these creative metaphors set the agenda in today's Chinese politics and society. More specifically, some metaphors are used to define the problem and trigger an evaluation of it, while others are mainly employed to propose a solution. Second, some of those metaphors that are seen as original and a feature of 'Xi's language style' are by no means new in Chinese political discourse. This is the case, in particular, of animals, disease and slovenly metaphors, which can all be traced back to the Maoist era. However, it is worth pointing out that Xi's use of Mao's language is much more a matter of auctoritas, rather than a coming back of Maoist China. This consideration is for two reasons: first, today's Party-state, the Chinese society and China's international relations are completely different from those of Mao's era, and hence metaphors necessarily acquire a different meaning. Second, even though these metaphors are used for the same purposes as in Mao's talks, especially revitalizing morality among Party's members, Mao's legacy is not undermining Beijing's approach to economic development. So, as Golden (2015) compellingly argues, "perhaps Xi is 'talking the Mao talk' but 'walking the Deng walk'” (4). One of the aims of 'talking Mao's words' may be just safeguarding 'Deng's walk' from the extreme left-wing voices inside the Party and in the PRC at large - the so-called neo-Maoist - who are particularly critical of economic reforms and market economy.

For the ideological implications of these creative metaphors, the analysis is multilayered, since it needs to take into account not merely the ideologies conveyed by metaphors per se, but also those sustained by the publications focusing on Xi Jinping's political communication. For the first level of analysis, it may be useful to move from van Dijk's definition of ideology, according to which ideology functions 
as the part of the socio-cognitive interface between social structures (conditions, etc.) of groups on the one hand, and their discourses and other social practices on the other hand. (van Dijk 2006, 117).

Metaphors are a way of doing things by manipulating the socio-cognitive interface. They can do so by changing the perspective when looking at an issue that people have in mind. For instance, the disease metaphors directly attach a negative evaluation to something.

However, in the case of Xi Jinping's use of these metaphors, the action performed by metaphors is two-pronged and not limited to the framing actions performed by metaphors per se. The second action made by these 'creative metaphors' is a passive one, since they are re-framed as being 'new' with the aim of making evident the originality of Xi's political communication and therefore of his governmental style. This process of reframing is the same one that the concept of the Chinese dream went through: starting from being framed as a goal pursued by the whole country, the Chinese dream has then been conceived as a political ideology and therefore as a tool to bring together the different parts of today's Chinese society.

This process of re-framing leads to the second level of ideological analysis. The publications on creative metaphors, as well as on other rhetorical devices mentioned above aiming at highlighting the originality of Xi Jinping's language style underpin a kind of charismatic-leader centred ideology: Xi has become both the political speaker and an object of study. In this way, he has become imbued with a special authority, by means of moulding his image as 'a man of the people', more specifically 'the man' who leads the country towards its rejuvenation.

In conclusion, entering into the debate on agency, Duranti (2004) suggests that a type of agency performed by language which is often overlooked is 'ego-affirming': "it is language per se as a human faculty rather than the meaning of its words that is sufficient for agency as ego-affirming to be at work" (Duranti 2004, 455). That is, the simple fact of speaking, independently from what has been actually said, is a form of action: "language already does something by being, before doing" (emphasis in the original) (Duranti 2004, 455). Applying this aspect of agency to Xi Jinping, it can be said that the kind of agency performed by publications around Xi's political communication is 'authoritative-affirming': it does not matter what meaning is conveyed in these publications focusing on Xi's speeches, the very fact of being collected is a form of action. 


\section{Bibliography}

Bai Tiantian (2018). "Party Paper Swears Loyalty to Lingxiu Xi” [online]. Global Times, 16 January. URL http://wWw.globaltimes.cn/content/1085070.shtml (2018-01-17).

Bakhtin, Michail Michajlovič (1981). The Dialogic Imagination. Four Essays. Ed. by Michael Holquist. Trans. by Caryl Emerson and Michael Holquist. Austin: University of Texas Press. Trans. of: Voprosy literatury i estetiki (Вопросы литературы и эстетики). Austin: University of Texas Press.

Bandurski, David (2017). "Xi Gets Research Centers to Match His Thought" [online]. China Media Project, 18 December. URL http:// chinamediaproject.org/2017/12/18/xi-gets-research-centers-tomatch-his-thought/ (2018-02-15).

Burgers, Christian et al. (2016). "Figurative Framing: Shaping Public Discourse Through Metaphor, Hyperbole, and Irony". Communication Theory, 26 (1), 410-30.

Buzzetti, Eugenio; Spalletta, Alessandra (2017). "Xi dopo il Congresso ha assunto un potere immenso" [online]. Spalletta, Alessandra (a cura di), La 'Nuova Era' Cinese. Roma: Alfabeto Treccani, 51-5. URL https:// images.agi.it/pdf/agi/agi/2017/12/23/112341295-bda89f96-f6be43e4-820c-8ab634413413.pdf (2018-02-07).

Callahan, William A. (2014). "What Can China Dream 'Do' in the PRC" [online]. The Asan Forum, 8 December. URL http://www. theasanforum. org/what-can-the-china-dream-do-in-the-prc/ (2016-06-04).

Charteris-Black, Jonathan (2004). Corpus Approaches to Critical Metaphor Analysis. New York: MacMillan.

Chen Rudong 陈汝东 (2014). Xiuci xue jiaocheng 修辞学教程 (Course Book on Rhetoric). Beijing: Peking University Press.

Chen Rudong 陈汝东 (2017). "Lun Zhongguo guojia huayu de fazhan qushi 论中国国家话语的发展趋势” (On the New Trends of Development in China's National Discourse). Academics, 225(2), 125-35.

Chen Xixi 陈锡喜 (ed.) (2014). Ping yi jin ren - Xi Jinping de yuyan liliang 平易近人一一习近平的语言力量 (Wit and Vision: The Power of Xi Jinping's Language). Shanghai: Jiaotong daxue chubanshe.

Cheng Hongyi 程宏毅; Chang Xuemei 常雪梅 (2017). “Xi de (Zhongguo fangan) - Xi Jinping yinyong de diangu mingju 习得(中国方案)——习近平引用的 古典名句” (Acquire Through Learning (China's solution) - Xi Jinping's Literary References) [online]. Renmin wang, 3rd February. URL http:// cpc. people.com.cn/n1/2017/0203/c64387-29054928.html (2018-02-07).

China Daily (2018). "Metaphors Used by Xi in Two Sessions" [online]. Xi's Moment. China Daily. URL http://show.chinadaily.com.cn/pub/view/ afc4b22a7117422cb7ab9fa3153b4785/htm (2018-03-03).

Cui Dahua (2007). "A Weakness in Confucianism: Private and Public Moralities". Frontiers of Philosophy in China, 2(4), 517-32. 
Dong Weiwu 董伟武; Yin Cheng 程银 (2014). “Xi Jinping huayu fengge yu xin shiqi Zhongguo makesizhuyi huayu tixi chonggou - Yi Xi Jinping zongshuji xilie zhongyao jianghua wei shijiao” 习近平话语风格与新时期中国马克思 主义话语体系重构——以习近平总书记系列重要讲话为视角 (Xi Jinping's Discursive Atyles and the Reconstruction of China's Marxist Discourse System for a New Era. Perspectives from the Series of Important Speeches by General Secretary Xi Jinping). Xiangchao 4, 9-14.

Duranti, Alessandro (2004). “Agency in Language”. Duranti, Alessandro (ed.), A Companion to Linguistic Anthropology. Malden (MA): Blackwell, 451-73.

Edelman, Murray (1971). Politics as Symbolic Actions: Mass Arousal and Quiescence. Chicago: Markham.

Entman, Robert (1993). "Framing: Toward Clarification of a Fractured Paradigm". Journal of Communication, 43(4), 51-8.

Fairclough, Norman (1989). Language and Power. Edinburg: Longman.

Fasulo, Filippo (2016). "Waking from the China Dream” [online]. Amighini, Alessia (ed.), China Dream: Still Coming True? ISPI Report. Novi Ligure: Edizioni Epoké, 13-31. URL http://www.ispionline.it/it/EBook/Rapporto Cina 2016/Rapporto cina_2016.pdf (2018-02-10).

Feng Pengzhi 冯鹏志 (2016). “Cong 'san ge zixin' dao 'si ge zixin'” 从“三个自信” 到“四个自信” (From the Three Self-confidences to the Four-confidences) [online]. Lilun-renmin wang, 7 July. URL http://theory.people.com.cn/ n1/2016/0707/c49150-28532466. html (2018-02-07).

Fumian, Marco (2013). “Do Not Awaken the Sleepers: Ironies and Paradoxes of the Chinese Dream" [online]. China Policy Institute, 8 July. URL https://cpianalysis.org/2013/07/08/do-not-awaken-the-sleepersironies-and-paradoxes-of-the-chinese-dream/ (2018-04-12).

Gao Shan 高杉 (2015). “Xi Jinping yindao zheyang de 'xin guanhua'” 习近平 引导这样的“新官话”风气 (Xi Jinping Leads this New Trend of a New Official Language)" [online]. Renmin wang, 12 January. URL http://politics. people.com.cn/n/2015/0112/c1001-26366347.html\# (2018-01-17).

Goatly, Andrew (2007). Washing the Brain. Metaphor and Hidden Ideology. Amsterdam; Philadelphia: John Benjamins Publishing Company.

Goffman, Ervin (1974). Frame Analysis: An Essay on the Organization of the Experience. Cambridge (MA): Haward University Press.

Golden, Sean (2015). “Mao' Place in Xi's 'China Dream'”. Notes Internacionales CIDOB, 130, October, 1-5.

Huang, Cary (2014). "Studies of Xi Jinping Thought or ideology grab lion's share of funding for research" [online]. South China Morning Post, 5 October 2014. URL http://wWW.scmp.com/news/china/article/1609734/ studies-xi-jinpingthought-or-ideology-grab-lions-share-fundingresearch (2018-02-08).

Jing-Schmidt, Zhuo; Peng, Xinjia. (2017). “Winds and Tigers: Metaphor Choice in China's Anticorruption Discourse". Lingua Sinica, 3(1), 1-26. 
Lakoff, George; Johnson, Mark [1980] (2003). Metaphors We Live By. Chicago: University of Chicago Press.

Lavagnino, Alessandra (2017). “From 'Chinese Characteristics' (Zhongguo Tese 中国特色) to 'Chinese Dream' (Zhongguo Meng 中国梦)-The Chinese Political Discourse Today”. Beretta, Silvio et al. (eds.), Understanding China Today. An Exploration of Politics, Economics, Society, and International Relations. Cham: Springer International Publishing Switzerland, 275-88.

Li Weihong 刘卫红 (2017). “Zhengzhi yinyu yu guojia xingxiang de huayu jiangou” 政治隐喻与国家形象的话语建构——— 《平易近人一_一习近平的语言力 量》评介 (The Discursive Construction of Political Metaphors and National Image. Comments on 'Wit and Vision: The Power of Xi Jinping's Language). Journal of Zhongyuan University of Technology, 28(2), 29-41. Link, Perry (2013). An Anatomy of Chinese. Rhythm, Metaphor, Politics. Cambridge (MA); London: Harvard University Press.

Liu Jin 刘进 (2013). “Lun Xi Jinping jianghua de huayuli” 论习近平讲话的话语力 (On the Discourse Power of Xi Jinping's Speeches). Wuhan ligong daxue xuebao (shehui kexue ban), 26(4), 569-73.

Liu Zhuihui 刘志辉 (ed.) (2017). Ping yi jin ren: Xi Jinping de yuyan liliang - junshijuan 平易近人一一习近平的语言力量 军事卷 (Wit and Vision: The Power of Xi Jinping's Language. On Military Affairs) Shanghai: Jiaotong daxue chubanshe.

Lu, Xing (2004). The Rhetoric of the Chinese Cultural Revolution: The Impact on Chinese Thought, Culture, and Communication. Columbia (SC): University of South Carolina Press.

Lu, Xing (2017). The Rhetoric of Mao Zedong: Transforming China and Its People. Columbia (SC): University of South Carolina Press

Lu, Louis W-L; Ahrens, Kathleen (2008). “Ideological Influences on BUILDING Metaphors in Taiwanese Presidential Speeches”. Discourse and Society, 19(3), 383-408.

Ma Zhong 马忠; Li Shuanggen 李双根 (2014). “Xi Jinping de wenfeng shijian ji dui dangqian qunzhong luxian huayu zhuanbian de jiazhi" 习近平的文 风实践及对当前群众路线话语转变的价值 (The Value of Xi Jinping's Style for the Evolution of the Discourse on the Current Mass Line Campaign). Guangxi shehui kexue, 2, 1-5.

Magagnin, Paolo (2017). "Putting into Practice 'Core Confucian Values'. Intertextuality and Ideology in Xi Jinping's May 4th 2014 Speech”. Mottura, Bettina et al. (eds.), Media \& Politics. Discourses, Cultures, and Practices. Newcastle upon Tyne: Cambridge Scholars Publishing, 225-40.

Mao Zedong 毛泽东 (1942). “Mao Zedong: Zai Yan'an wenyi zuotanhui shang de jianghua” 毛泽东: 在延安文艺座谈会上的讲话 (Mao's Speech at the Forum on Literature and Art) [online]. Renmin wang. URL http://culture. people.com.cn/GB/22226/243327/243332/17858551.html (2018-05-12).

Miranda, Marina (2017). “Le Ambizioni del Pensiero di Xi Jinping per una 'Nuova Era'”. Orizzonte Cina, 8(5), 13-6. 
Müller, Ralph (2005). “Creative Metaphors in Political Discourse. An Analysis of Swiss Speeches". metaphorik.de, 9, 53-73.

Musolff, Andreas (2004). Metaphor and Political Discourse. Analogical Reasoning in Debates about Europe. New York: Palgrave Macmillan.

Ottati, Victor et al. (2014). "The Metaphorical Framing Model: Political Communication and Public Opinion". Landau, Mark J. et al. (eds.), The Power of Metaphor: Examining its Influence on Social Life. Washington, DC: American Psychological Association, 179-202.

Peng Longfu 彭龙富 (2015). “Xi Jinping de yuyan yishu tansuo” 习近平的语言 艺术探析 (Exploring the Language Skills of Xi Jinping). Zhonggong Hefei shiwei dangxiao xuebao, 2, 59-64.

Reese, Stephen D. (2007). "The Framing Project: A Bridging Model for Media Research Revisited". Journal of Communication, 57, 148-54.

Renmin ribao pinglunbu 人民日报评论部 (2015). Xi Jinping yong dian 习近平 用典 (Quotations by Xi Jinping). Beijing: Renmin ribao chubanshe.

Renmin ribao pinglunbu 人民日报评论部 (2017). Xi Jinping jiang gushi 习近 平讲故事 (Anecdotes by Xi Jinping). Beijing: Renmin ribao chubanshe.

Renmin ribao pinglunbu 人民日报评论部 (2018a). Xi Jinping yong dian di er 习 近平用典第二 (Quotations by Xi Jinping, Second Volume). Beijing: Renmin ribao chubanshe.

Renmin ribao pinglunbu 人民日报评论部 (2018b). Xi Jinping jiang gushi (Shaonian ban) 习近平讲故事 (少年版) (Anecdotes by Xi Jinping - Kids Edition). Beijing: Renmin ribao chubanshe.

Renmin wang 人民网 (2017). “Tuanjie: Cong Xi Jinping de shi ge biyu kan 'Yi Dai Yi Lu' lantu” 图解: 从习近平的十个比喻看'一带一路”蓝图 (Illustration: Looking at the 'One Belt, One Road' Roadmap from 10 of Xi Jinping's Metaphors) [online]. Renmin wang, 12 May. URL http://politics.people.com.cn/n1/2017/0512/c1001-29272044.html (2018-02-27)

Richards, Ivor Armstrong (1936). The Philosophy of Rhetoric. London: Oxford University Press.

Scarpari, Maurizio (2015). Ritorno a Confucio. La Cina fra Tradizione e Mercato. Bologna: il Mulino.

Schoenhals, Michael (1992). Doing Things with Words in Chinese Politics: Five Studies. Berkeley (CA): Center for Chinese Studies.

Ambrogio, Selusi (2017). "Moral Education and Ideology: The Revival of Confucian Values and the Harmonious Shaping of the New Chinese Man”. Asian Studies, 5(2), 113-35.

Thøgersen, Stig (2006). “Beyond Official Chinese: Languages Codes and Strategies". Thøgersen, Stig; Heimer, Maria (eds.), Doing Fieldwork in China. Honolulu; Copenhagen: NIAS Press, 110-26.

Van Dijk, Teun (2006). “Ideology and Discourse Analysis”. Journal of Political Ideologies, Routledge, 11(2), 115-40.

Wang Zhen (2017). "Fifty Shades of Xi: Scores of Books Praising President Published in China" [online]. The Guardian, 10 October. URL https:// 
WWw.theguardian.com/world/2017/oct/10/fifty-shades-of-xi-scoresof-books-praising-president-published-in-china (2018-03-01).

Wei Chuanguang 魏传光 (2006). “Zhongguo yujing xia san zu gongmin duiying gainian de shuli yu zhuanhuan" 中国语境下三组公民对应概念的梳理与转换 (Three Conceptualization of Citizens in the Chinese Context). Sixiang lilun jiaoyu, 5, 38-42.

Wells, Audrey (2001). The Political Thought of Sun Yat-sen. Development and Impact. Basingstoke: Palgrave Macmillan.

Wen Xiu 文秀 (2014). “Xi Jinping jianghua de yuyan fengge ji tedian” 习近平 讲话的语言风格及特点 (The Style and Features of Xi Jinping's Language). Lilun daobao, 1, 6-8.

Wo-Lap Lam, Willy (2017). “Has Xi Jinping Become 'Emperor for Life'?” [online]. URL https://jamestown.org/program/xi-jinping-becomeemperor-life/ (2018-01-10).

Xi Jinping 习近平 (2014a). Xi Jinping tan zhi guo lizheng 习近平谈治国理政 (The Governance of China). Beijing: Waijiao chubanshe.

Xi Jinping (2014b). The Governance of China. Beijing: Foreign Language Press.

Xi Jinping (2017a). Xi Jinping tan zhi guo lizheng di er juan 习近平谈治国理政第二 卷 (The Governance of China, Second Edition). Beijing: Waijiao chubanshe.

Xi Jinping (2017b). The Governance of China II. Beijing: Foreign Language Press.

Xi Jinping (2017c). "Jiesheng quanmian jiancheng xiaokang shehui duoqu xin shidai Zhongguo tese shehuizhuyi weida shengli - Zai Zhongguo gongchandang di shi jiu ci quanguo daibiao dahui shang de baogao" 决胜全面建 成小康社会 夺 取新时代中国特色社会主义伟大胜利 ——在中国共产党第十九次全国 代表大会上的报告 (Secure a Decisive Victory in Building a Moderately Prosperous Society in All Respects and Strive for the Great Success of Socialism with Chinese Characteristics for a New Era) [online]. Xinhua, 27 October. URL http://news . xinhuanet.com/politics/19cpcnc/201710/27/c_1121867529.htm (2018-02-05).

Xinhua (2018a). "Amendments proposed for Constitution" [online]. Xinhua, 25 February. URL http://www.chinadaily.com.cn/a/201802/25/ WS5a927386a3106e7dcc13dece.html (2018-02-28).

Xinhua (2108b). "Wu nian liang hui, Xi Jinping zhi yu yan qian yi shen" 5年两会, 习近平之喻言浅意深 (Two Sessions over the Past Five Years, Xi Jinping's Metaphors. Plain Language and Profound Meanings). Xinhua, 28 February. URL http://wWw.xinhuanet.com/politics/201802/28/c_129818874.htm (2018-03-03).

Yao Lijun 姚莉君; Li Chunmei 李春梅 (2016). “Xi Jinping de huayu fengge ji qi tedian” 习近平的话语风格及其特点 (Xi Jinping's Discursive Style and Its Features). Dang qing guo qing, 403(1), 1-2.

Zhang Haifa 张海法; Hu Zhongbing 胡中冰 (2014). “Xi Jinping de 'qunzhong yuyan'” 习近平的 “群众语言' (Xi Jinping's 'Language of the Masses'). Zatansuibi, 3, 61 . 
